\title{
Margin Requirements, Volatility, and Market Integrity: What have we learned since the Crash?
}

\author{
Paul H. Kupiec ${ }^{\dagger}$
}

April 1997

${ }^{\dagger}$ Senior Economist, Trading Risk Analysis Section, Division of Research and Statistics, Board of Governors of the Federal Reserve System. The conclusions herein are those of the authors and do not represent the views of the Federal Reserve Board or any of the Federal Reserve Banks. I am grateful to Pat White, Pat Parkinson, Greg Duffee, and Katherine Allen for helpful discussions. Mail Stop 91, Federal Reserve Board, Washington, DC, 20551, 202-452-3723, email:pkupiec@frb.gov 


\begin{abstract}
This study assesses the state of the policy debate that surrounds the Federal regulation of margin requirements. A relatively comprehensive review of the literature finds no undisputed evidence that supports the hypothesis that margin requirements can be used to control stock return volatility and correspondingly little evidence that suggests that margin-related leverage is an important underlying source of "excess" volatility. The evidence does not support the hypothesis that there is a stable inverse relationship between the level of Regulation T margin requirements and stock returns volatility nor does it support the hypothesis that the leverage advantage in equity derivative products is a source of additional returns volatility in the stock market.
\end{abstract}




\section{Introduction and Overview}

The Securities Exchange Act of 1934 granted the Federal Reserve Board (FRB) power to set initial, maintenance, and short sale margin requirements on all securities traded on a national exchange for purposes of regulating the securities credit extended by exchange members. Pursuant to this authority, the FRB established Regulation T (Reg $\mathrm{T}$ ), the rules governing the percentage of equity value a broker/dealer was allowed to lend on exchange-traded securities. ${ }^{1}$ Although securities markets have a long history of Federal margin regulation, not until 1992, when the U.S. Congress extended the FRB's margin setting authority to include the levels of margin on stock index-futures contracts, was a Federal regulator responsible for setting margin levels for futures products. $^{2}$

Initial margin requirements in the equity market determine the maximum loan value of a security. For example, if the initial margin requirement were set at 40 percent, an investor could post a marginable security as collateral and borrow up to 60 percent of the security's value. Alternatively, if the investor were to buy the security on margin, the investor would be required to deposit at least 40 percent of the value of the security in a margin account to complete the margin transaction.

In contrast to Reg $\mathrm{T}$ margin requirements, margin requirements in equity derivative markets are collateral requirements designed to ensure contract performance. From an economic perspective, there is no extension of credit in equity derivative

\footnotetext{
${ }^{1} \operatorname{Reg} \mathrm{T}$ was subsequently followed by Regulation $\mathrm{U}$, the rules that extend Reg $\mathrm{T}$ margin requirements to bank security lending; Regulation $\mathrm{G}$, the rules that govern securities lending by all other domestic lenders; and Regulation X, the guidelines for the extension of securities credit by foreign lenders. Until the introduction of exchange-traded equity option in 1973, the FRB did not exercise its authority to establish uniform margin requirements for stock options.

${ }^{2}$ The CFTC has always had regulatory authority to approve futures clearinghouse margining systems (17CFR Section 1.41). Although the CFTC had the authority to approve the margining systems, sections 5(a)(12) and 8(a)(7) of the Commodity Exchange Act (CEA) expressly precluded the CFTC from exercising authority over the level of margins for futures transactions. An exception is granted under Section $8(\mathrm{a})(9)$ of the CEA, where the CFTC is granted authority under its emergency powers clause to set temporary margin levels in order to maintain or restore orderly trading in the futures markets.
} 
markets. ${ }^{3}$ Despite differences in their form and function, the margin requirements on equity derivative contracts affect the cost of taking positions and implicitly define the maximum amount of return leverage that can be obtained in such contracts.

The 1934 U.S. Congress established Federal margin authority with three apparent objectives: to reduce the use of "excessive" credit in securities transactions; to protect investors from over-leveraging; and to reduce the volatility of stock prices. ${ }^{4}$ The Congress evidently believed that a federal margin policy could be used to control the amount of credit allocated to "unproductive" investment in the stock market and thereby reduce the effects of destabilizing speculation on stock prices. The view prevailing in Congress held that there existed a fixed pool of credit available to support investment activities, and any credit that was used to purchase stocks was credit that was unavailable to finance productive investments in new plant and equipment. Moreover, it was widely believed that stock-related credit supported the activities of speculators whose trading activities allegedly created unnecessary volatility in the stock market.

In apparent sympathy with the views held in the U.S. Congress, the evidence suggests that until at least the late 1960s, the Federal Reserve Board exercised margin authority in a spirit aligned with the original Congressional intent. Indeed, in U.S.

\footnotetext{
${ }^{3}$ The legal profession may have a difference of opinion. Historically, Reg $\mathrm{T}$ required that long options be paid for in full (a 100 percent margin requirement). Under recently adopted Reg $\mathrm{T}$ rule changes, long-options will be eligible to receive collateral value, but not until the NYSE modifies its rules to accommodate this change. Thus, historically, it was legally impossible to obtain a loan using options as collateral. However, from a legal point of view, options apparently are viewed as an extension of credit. As near as I can tell, the legal argument is as follows: the writer of the option is extended credit by the option purchaser because the purchaser is subject to the risk of contract performance. The legal interpretation that performance risk is an extension of credit to the option writer apparently was the argument used to assert legal jurisdiction over equity option margin requirements under Sections 7 and 8 of the 1934 Securities and Exchange Act (please consult your own securities attorney before acting on this historical interpretation). Regardless of the legalities, from an economic standpoint, the margin requirements on a written options satisfy a prudential function and are not related to any economic extension of credit. See Rutz and Sinquefield (1985) for a comparison of the role margin requirements on stocks and futures contracts.

${ }^{4}$ Moore (1966) summarizes the discussion that transpired in the Congressional hearings on margin authority. Alternatively, see the discussion in France (1991).
} 
Senate testimony in 1955, FRB Chairman Martin summarized the FRB's view on margin policy:

The task of the Board, as I see it, is to formulate regulations with two principal objectives. One is to permit adequate access to credit facilities for securities markets to perform the basic economic functions. The other is to prevent the use of stock market credit from becoming excessive. The latter helps to minimize the danger of pyramiding credit in a rising market and also reduces the danger of forced sales of securities from undermargined accounts in a falling market..$^{5}$

As federal margin authority has yet to be repealed, the U.S. Congress may still hold the view that margin requirements can be effective as a selective credit control and useful as a tool for stabilizing stock prices. Notwithstanding the opinions of those that share the 1934 Congressional viewpoint, the majority in the finance profession appear to have abandoned the beliefs that underlie the original margin authority mandate. Few believe that selected credit controls are an efficient way to limit the volume of credit extended, and the majority view is that margin requirements have no predictable effect on stock price volatility. Indeed a 1984 staff study by the FRB, "A Review and Evaluation of Federal Margin Regulations," concluded that margin requirements were ineffective as selective credit controls, inappropriate as rules for investor protection, and were unlikely to be useful in controlling stock price volatility.

Prior to the 1987 stock market crash, little academic evidence suggested that margin policy was effective in accomplishing the goals behind the 1934 authorization. ${ }^{6}$ By the early 1980s, the academic research on margin policy had shifted focus from evaluating the effects of changes in Reg T margins to analyzing the procedures appropriate for setting prudential margins in the futures markets. ${ }^{7}$ The shift in research

\footnotetext{
${ }^{5}$ Chairman Martin's testimony before the U.S. Senate Committee on Banking and Currency, 84th Congress, 1955 as quoted in Moore (1966), p. 163.

${ }^{6}$ See for example, Moore (1966), Officer (1973), Largay and West (1972), or Grube, Joy and Panton (1979).

${ }^{7}$ See for example, Telser (1981), Figlewski (1984), or Edwards (1983).
} 
focus likely reflected two distinct forces: first, the belief that the most interesting issues surrounding Reg T margin policy were more-or-less settled; the second influential force was the expansion of financial futures trading that increased the importance and interest in the largely unregulated margin policies of the futures clearinghouses.

The 1987 stock market crash and the studies that followed rekindled interest in margin policy and spawned a political and academic debate on the efficacy of margin policy for common stocks and their derivative products. Although all the major stock market crash studies discussed margin policy in the context of market integrity, the studies reached significantly different conclusions.

The New York Stock Exchange's report on the crash, the so-called Katzenbach Report (1987) concludes (p. 16):

. . margin rules provide the Federal Reserve Board with an effective tool for controlling the amount of leverage that may be used in securities transactions and, ultimately, the ease with which speculation may occur. The margin rules thus provide the FRB with a means to prevent and control market fluctuations and help stabilize the economy in general.

Although the Katzenbach report contradicts the findings of the FRB's 1984 margin study, the report does not provide any evidence to justify this difference of opinion. After establishing its position on margin efficacy, the report then observes that the low margins and trading costs associated with stock index futures products create a sizeable leverage advantage compared to the leverage that can be achieved in the cash market. Given this observation, the report concludes that the leverage in index futures products encourages speculation that ultimately leads to greater volatility in the cash markets. The report recommends raising margin requirements on stock index futures contracts and changing futures settlement procedures to remove the leverage advantage enjoyed by stock index futures products.

In its margin policy recommendations, the Securities and Exchange Commission's Report, "The October 1987 Market Break (1988)," largely concurs with the recommendations of the Katzenbach Report. The SEC's report recommends (p. xiv-xv), 
. . . thought should be given to steps to bring the available leverage of derivative products in line with the leverage of stock products. ... the margin treatment for stock index futures and options provides significantly higher leverage for users of these products that [sic] can be achieved under stock margin requirements. ..., the Division [Market Regulation] believes that relatively low margins may contribute to increased concentrated institutional trading and resulting greater price volatility.

In contrast to the aforementioned studies, neither the Brady Commission Report or the Report of the President's Working Group on Financial Markets explicitly call for raising derivative product margin requirements. The Brady Commission Report (1988), "Report of the Presidential Task Force on Market Mechanisms," concludes that (p. vii), "Margins should be made consistent across marketplaces to control speculation and financial leverage." It is perhaps notable that, although the Brady Commission seems to accept the hypothesis that volatility and leverage are related, it did not recommend increasing margins on equity derivative products to coincide with the 50 percent initial margin required on stock transactions. Although, the Brady Commission recommends equalizing leverage, the Commission was unwilling to suggest the appropriate level at which leverage should be equalized.

The "Interim Report of the Working Group on Financial Markets (1988)," the report jointly authored by the Secretary of the Treasury and the Chairpersons of the FRB, SEC, and CFTC, concludes that, for prudential purposes, the existing margin requirement settings for stocks and stock index futures products was adequate. Indeed the report concludes that, for prudential purposes, it is appropriate for margin requirements to differ across stock and stock index derivative products. The principals were, however, unable to agree on whether or not margin policy could be effectively used to control stock market volatility. Chairman Ruder of the SEC held the view that raising futures margins would reduce volatility in the cash market. Chairman Greenspan of the FRB, Chairman Gramm of the CFTC, and Secretary Gould of the Treasury did not believe that the evidence supported the view that higher margins 
discourage volatility while they did find compelling the evidence that suggests that higher futures margins reduce market liquidity.

Recommendations that margin requirements should be set to coordinate the leverage in stock and stock derivative contracts led some to suggest regulatory changes that would entrust stock and stock derivative margin-setting policy to a single regulator. ${ }^{8}$ Ultimately, these recommendations led the U.S. Congress to grant the FRB margin setting authority for stock index futures contracts in 1992. The FRB exercised this mandate by delegating regulatory authority over stock index futures contracts to the CFTC in 1993.

The margin policy controversy apparent in the official reports that analyzed the 1987 Crash generated renewed academic interest in margin policy research. In particular, an influential study by Hardouvelis (1988) concluded that historical evidence supported the proposition that margin requirements could be used to control stock market volatility. The conclusions of the Hardouvelis study were disputed by many subsequent studies and the margin-volatility literature expanded significantly. On balance, the empirical literature that follows the Hardouvelis study confirms the precrash academic view: there is little direct empirical evidence that supports the proposition that margin policy can be an effective tool in controlling stock market volatility. Despite the predominate academic finding, some still hold the view that margin requirements function as the 1934 Congress envisioned. Margin policy advocates support their position by claiming that the lack of strong direct econometric evidence can be easily explained. They claim that the true underlying margin-volatility relationship may be econometrically obscured by the infrequency with which margins have been changed, the substantial noise component in stock price and return data, and by the inappropriate measurement techniques used in most margin-volatility studies. ${ }^{9}$

\footnotetext{
${ }^{8}$ See for example the NYSE's (1990) study, "Market Volatility and Investor Confidence," Recommendation 8.

${ }^{9}$ See for example the discussion in Hardouvelis (1989).
} 
The purpose of this study is to assess the state of the margin policy debate using both the direct and indirect evidence that has accumulated since the 1987 Crash. In contrast to earlier literature reviews by France (1991) and Chance (1990), this study will not only discuss more recent evidence, but it will also incorporate the findings of the indirect but related literature that investigates the effects of derivative markets on cash market volatility.

The hypothetical relationship between margin requirements and volatility is driven by leverage. As a consequence, a necessary condition for the existence of a negative margin-volatility relationship is that there must be, on average, a positive association between leverage and the volatility in the underlying market. Indeed the margin recommendations of three of the major post-crash studies are premised on the hypothesis that leverage enables speculators to generate unnecessary volatility. Derivative contracts not only offer significant leverage advantages over cash market transactions, they also facilitate short-selling. Thus, if margin requirements affect volatility by constraining leverage, the introduction of a derivative market should have effects similar to those generated by a reduction in the cash market margin requirement. As a consequence, if there is a negative relationship between the level of margin requirements and volatility, this relationship should manifest itself if the form of higher volatilities following the introduction of a derivative contract. Moreover, once derivative product trading commences, leverage constraints will be determined by the level of margin in the derivative market as cash market margins will no longer be the binding constraint on speculators. Thus the results of studies that investigate the relationship between margin requirements and volatility in the futures market become directly relevant to the margin-volatility policy debate.

After examining the academic evidence that investigates the relationship between margin and volatility in both the cash and futures market, and considering the results of studies that measure the effects of derivative market introductions, this study concludes that there is no substantial body of evidence that supports the hypothesis 
that margin requirements can be systematically altered to manage the volatility in stock markets. The empirical evidence shows that, while high Reg T margin requirements may reduce the volume of securities credit lending and high futures margins do appear to reduce the open interest in futures markets, neither of these measurable effects appears to be systematically associated with lower stock return volatility. The evidence to date suggests that, contrary to the leverage arguments advanced by the pyramiding-depyramiding hypothesis and explicitly accepted by many of the official studies of the 1987 stock market crash, there is little or no empirical evidence that supports the hypothesis that tightening leverage constraints in either the cash or equity derivative markets will reduce stock return volatility.

\section{Reg T Margins, Leverage, and Volatility: the theory}

The view held by the 1934 U.S. Congress and those that continue to believe that high margin requirements attenuate volatility is that low initial margins enable speculators to exert undue influence in stock markets and thereby create excess volatility. It is

alleged that speculators force stock prices above their fundamental values through a process known as "pyramiding." Pyramiding refers to the dynamic in which gains in stock prices allow over-optimistic agents to borrow additional funds for equity purchases. These leveraged purchases in turn create additional upward pressures on equity prices and the gains can be used to borrow additional funds for further equity purchases. When the inevitable market correction begins, leveraged investors faced with margin calls are forced to liquidate positions. The "depyramiding" process allegedly causes overshooting of the fundamental equilibrium. As a result, low margin requirements create an additional source of volatility over the volatility attributable to fundamental economic forces.

Despite the intuitive appeal of this pyramiding-depyramiding argument, it is at best incomplete. It only identifies one possible avenue through which margin requirements may affect volatility. Goldberg (1985) develops a theoretical model that 
suggests a positive relationship between margin requirements and stock price volatility. In Goldberg's model, when investors are constrained by margin requirements, firms face incentives to increase their leverage. In the resulting general equilibrium, corporate leverage is substituted for the private leverage, and stock price volatility increases in response to increased corporate leverage.

Kupiec and Sharpe (1991) develop an equilibrium model in which irrational speculators may create excess stock price volatility. In contrast to the pyramidingdepyramiding hypothesis, this model suggests the possibility of a positive relationship between margin requirements and excess stock market volatility. The model demonstrates that high margin requirements may reduce the equity purchases of liquidityconstrained investors when a fundamental economic shock causes a decline in equity prices. Because those that are willing to bear risk are constrained from borrowing to purchase additional shares, equity prices fall below their fundamental values. Thus, higher margin requirements create greater equity price volatility; conversely, low margins reduce stock price volatility. Depending on the characteristics of investors in the model, consistent with the pyramiding-depyramiding hypothesis, it is also possible for margins to reduce volatility in the Kupiec-Sharpe model by constraining the leverage of irrationally optimistic agents. Given the possibility of these two polar cases, the Kupiec-Sharpe model establishes that there is no unique theoretical relationship between margin requirements and asset price volatility; from a theoretical standpoint it is equally plausible that low margin requirements may reduce stock price volatility as increase it. Indeed, over time, the effects of margin requirements may vary as the sources of excess stock price volatility change over time.

\section{Margins, Leverage, and Volatility: evidence from the stock market}

Prior to the late 1980s, virtually all published academic evidence suggested that changes in the Reg $\mathrm{T}$ margin requirements had no statistically measurable effect on stock price volatility when volatility was measured by the standard deviation of the 
returns on a broad stock market index. ${ }^{10}$ In summarizing the early literature, it is instructive [and perhaps timely] to revisit the conclusions of Moore (1966), Margin requirements add to paper work and to the costs of stock market transactions; ... and, most important, they fail to fulfil their stated objectives. However, they do give the Federal Reserve a way of expressing its concern with movements in the stock market. But statements by the Federal Reserve setting forth its view might be substituted for changes in margin requirements, if the Federal Reserve feels a need to voice its view of stock market activity. (p. 167)

A 1988 study by Hardouvelis disputed Moore's conclusions and the results of earlier academic findings and concluded that, over the 1934-1987 period, monthly stock return volatility is systematically related to the level of Reg $\mathrm{T}$ margin requirements. Hardouvelis finds evidence of a statistically significant negative correlation between the level of margins and the volatility of monthly S\&P500 stock returns. He interprets this correlation in a causal way, and concludes that Reg $\mathrm{T}$ margin requirements can be used to attenuate stock price volatility. Contrary to the existing literature, not only does Hardouvelis find a statistically significant negative margin-volatility relationship, but he claims that changes in margins can cause substantial changes in monthly stock return volatility. According to Hardouvelis (pp. 87-88) a 10 percentage point increase in the Reg $\mathrm{T}$ margin requirement will on average result in an 8 percent decline in stock return volatility in the following month and greater reductions in the long-run. ${ }^{11}$ In an expanded study, Hardouvelis (1990) affirms his 1988 study's findings using a different measure of monthly stock return volatility.

Subsequent (or coincident) to the original Hardouvelis (1988) study, and the expanded analysis in Hardouvelis (1990), a bevy of studies re-examined the marginvolatility issue. Ferris and Chance (1988), Schwert (1989a, 1989b), Salinger (1989),

\footnotetext{
${ }^{10}$ See the references in note 6 .

${ }^{11}$ His estimates suggest that the long-run effect for small stocks would be about a 15 percent reduction in monthly return volatility.
} 
Kupiec (1989), and Hsieh and Miller (1990) all empirically investigated the hypothesis that Reg $\mathrm{T}$ margin requirements and stock price volatility are inversely related. Using different econometric techniques to evaluate time series aggregate stock returns data, without exception, these studies find no support for an inverse margin-volatility relationship. The upshot of the results of these studies is that increases in volatility appear to preceded increases in margin requirements, and increases in margin requirements do seem to depress the volume of margin credit extended, but there is no evidence to suggest that the level of margin requirements and stock return volatility are systematically related.

How can the results of the Hardouvelis studies differ so sharply from those of other researchers? Hsieh and Miller (1990) directly investigate this question. The Hardouvelis (1988) study measured monthly return volatility using a 12-month rolling standard deviation estimate. The use of a rolling standard deviation introduces substantial positive autocorrelation in monthly measures of volatility. In his analysis, Hardouvelis regresses overlapping monthly volatility estimates on 12-month moving averages of Reg T margin requirements, and in an expanded regression, includes the moving average of margin credit as well.

Hsieh and Miller show that the moving average constructions used by Hardouvelis induce a spurious correlation between his measures of margin requirements and volatility. If one properly accounts for this correlation, Hsieh and Miller show that there is no statistically significant margin-volatility relationship. Moreover, according to the pyramiding-depyramiding hypothesis, if margins are to have an affect, they must do so by altering the level of margin credit. As a consequence, margin credit should not be included as an an explanatory variable in Hardouvelis's expanded regression if it is attempting to measure the volatility-magnifying effects of leverage. If margin credit is included, the volatility regression measures the effect of margin requirements on volatility, holding constant the level of margin credit. According to the pyramiding-depyramiding hypothesis, there should be no margin effect if margin 
credit is held fixed, and so the expanded Hardouvelis model is badly misspecified if it is attempting to measure the effect of margin requirements on stock price volatility. When Hsieh and Miller correct the Hardouvelis (1988) analysis for these problems, they demonstrate that the claimed margin-volatility relationship vanishes.

In Hardouvelis (1990), monthly stock return volatility is measured as a multiple of the absolute value of the residuals generated from a regression of monthly returns on lagging 12 month returns and 12 monthly dummy variables. Hardouvelis claims that this volatility estimate is a modification of the volatility estimate proposed in Schwert (1989a, 1989b). Hsieh and Miller (1990) examine this modified Schwert estimator and demonstrate that the Hardouvelis modifications destroy the integrity of the original Schwert volatility estimator. Instead of a close correspondence with more traditional measures of volatility, Hsieh and Miller show that the Hardouvelis measure produces volatility estimates with extremely undesirable sample properties including a preponderance of extreme volatility estimates in the sample period. Hsieh and Miller conclude that this volatility measure is unsuitable for analysis.

The findings of the series of studies that directly revisit Hardouvelis's analysis are augmented by studies that investigate the margin-volatility hypothesis using entirely different experimental designs. Grube, Joy and Howe (1987) examine the abnormal return effects generated when non-marginable OTC securities gain margin eligibility status. They find that these OTC stocks experience a statistically significant abnormal positive price appreciation when they are included the FRB's margin eligibility list, and little price effect if they a subsequently removed from the list of marginable securities. They interpret their findings as consistent with a Fed endorsement effect or a convenience effect. ${ }^{12}$

\footnotetext{
${ }^{12}$ When an OTC security in not marginable, investors must acquire the stock certificate and use it as collateral to obtain credit somewhere. This is presumably costly. Once marginable, the security can be left in street name at the broker and used as collateral in a margin account. Grube, Joy and Howe speculate that a subsequent delisting may not have an effect owing to a grandfather clause in Reg $\mathrm{T}$ that prohibits new loans but allows existing lending arrangements to continue.
} 
Seguin (1990) also studies the effects generated when a sample of previously nonmarginable OTC stocks gain margin eligibility. In contrast to Grube, Joy and Howe (1987), Seguin studies the events' effect on volatilities, trading volumes, returns, and return autocorrelations. Seguin finds that, on average, margin eligibility is associated with a 2 percent decline in return volatility, about a 2 percent increase in average share value, and about a 30 percent increase in trading volume where all the aforementioned effects are statistically significant. ${ }^{13}$

Seguin and Jarrell (1993) examine the pyramiding-depyramiding hypothesis by examining the relative return and volume behavior of marginable and non-marginable stocks during the October 1987 stock market crash. They argue that, since margin credit was at a historical high during October 1987, and there is evidence that the Crash precipitated substantial margin call activity, if depyramiding price pressures exist, they should be especially evident in the return profiles of marginable stocks during the Crash period. Seguin and Jarrell find that during the Crash, marginable securities experienced higher excess volumes relative to non-marginable securities (14 to 40 percent higher) as predicted by the margin-call depyramiding hypothesis. ${ }^{14}$ Despite greater excess trading volumes, Seguin and Jarrell find that the price declines recorded by marginable securities were less severe (returns were 0.8 percent greater) that those recorded by non-marginable securities.

\section{Derivative Markets, Leverage, and the Margin-Volatility Debate}

In the late 1980s the margin volatility debate moved from Reg T margin requirements to the margin requirements on stock-index futures products. Margin requirements in futures markets serve as a performance bond guarantee. In futures markets, margins are designed to protect the futures clearinghouse from the risk that is generated from a single-day's potential loss in a contract's value. Owing to the institutional differences

\footnotetext{
${ }^{13}$ Seguin finds no statistically significant changes in return autocorrelation patterns.

${ }^{14}$ Seguin and Jarrell present evidence that suggests that the higher excess volume likely owes in part to forced margin-call sales.
} 
in futures-style trading and settlement, the margin needed to control a clearinghouse's one-day risk exposure on a futures contract is far smaller than the 50-percent initial margin requirement that has been set by the FRB to "protect" lenders in security transactions.

The difference in required margin between a futures and cash transaction creates a leverage advantage for stock index futures products. Similarly, the leverage available using individual stock options dominates that available in the cash market. Moreover, individual stock options and stock index futures allow traders to circumvent the shortselling rules that prevail in the cash market. ${ }^{15}$ If leverage is the source of "excess" volatility in stock markets, the introduction of stock options and stock index futures trading should have had measurable effects on the volatility in the stock market.

Those who associate leverage with speculation and excess volatility have noted the advantages accorded futures products. These views are expressed in the "Katzenbach Report," (p. 28)

The trivial cost and tremendous leverage available make index futures and options an ideal instrument for speculation in short-term market movements. Speculation is in the index-the market itself-and the futures and options market reacts far more quickly to macroeconomic factors than does the underlying market, precisely because it is an index product. . . . To quite a substantial extent, the tail is wagging the dog.

Although it is clear that stock-index futures products and options transactions have a significant transactions cost and leverage advantage over direct cash-market purchases or sales, it is an open question whether or not this leverage advantage is of any consequence for the volatility of returns in the underlying stock market. There are at least two separable aspects to this question: first, does the existence of a derivatives market effect the return volatility of the underlying instrument; and secondly, given the existence of the derivative product, does a change in its margin requirement impact the price volatility of the underlying. The subsequent sections

\footnotetext{
${ }^{15}$ For a discussion, see Cox and Rubinstein (1985) or Manaster and Rendleman (1982).
} 
will review the scientific evidence that relates to these logically separable issues.

\section{Derivatives and Cash Market Volatility: the theory}

Theoretical models can be constructed to examine the effects of introducing a derivative market on the volatility in the underlying cash market. Turnovsky and Campbell (1985) develop an equilibrium model designed to assess the volatility and welfare implications associated with the introduction of a futures market. Because their model is highly nonlinear, they can only simulate equilibria. They find that, in virtually all model calibrations, the introduction of a futures market either stabilizes cash market prices or has no effect on volatility. Weller and Yano (1987) also analyze this question in a two-good, two-agent model with exogenous stochastic output. They find that the introduction of a futures market has two effects: a price arbitrage effect and an wealth transfer effect. The price arbitrage effect unambiguously reduces price volatility in the cash market, but the volatility effects engendered by the wealth transfers that result from futures market trading are ambiguous as they depend on the heterogeneity in the trading populations' utility functions.

Detemple and Selden (1991) model the effects of introducing a call option contract into an incomplete market setting where assets include only a stock and risk free bond. They show that the price and return volatility of the stock will in general be affected by the introduction of the derivative security. For a given set of endowments, when a derivative is introduced into an incomplete market setting with sufficiently diverse agents, the derivative contract will be traded. Derivative trading will facilitate a reallocation of consumption which will be reflected by a change in the equilibrium price and return characteristics of the underlying security. In a specialized quadratic utility example, Detemple and Seldon show that the introduction of the derivative will increase the price of the security and reduce its return volatility.

Stein (1987) develops a theoretical model in which the introduction of a futures market can destabilize cash market prices. In the Stein model, the presence or absence 
of a futures market does not affect speculators by altering their leverage constraint. Rather, misinformed speculators are unable to trade in the spot market by assumption. When a futures market is introduced, speculators can trade and their trading may affect the information content of spot market prices. In this setting, Stein establishes the theoretical possibility that the "noise" in speculators information sets can create spot market price volatility that cannot be distinguished from underlying "fundamental" volatility by the other traders in his model. The opening of a futures market allows the imperfectly informed speculators to trade, and their trading distorts the information content of market-clearing spot prices. Because spot traders are risk averse and cannot differentiate between price shocks that owe to fundamental supply disturbances and price shocks caused by the demands of imperfectly informed speculators, their inventory holdings are less responsive to price shocks when imper-

fectly informed speculators are allowed to trade in the futures market. The change in spot traders inventory holdings leads to additional spot price volatility and reduced social welfare.

Stein interprets his model as a formal counter-example to the conjecture that the addition of speculators to an existing market will add to the depth and liquidity of a market and thereby reduce the price effects created by transitory shocks to demand or supply. Even though agents voluntarily trade with the new futures market speculators, they can be made worse off. Stein's results are a specific example of Hart's (1975) general finding that, when markets are incomplete, opening an additional market may make agents worse off if markets remain incomplete. In both the Hart and Stein models, it is notable that leverage does not play role in generating the destabilizing price speculation or the loss in social welfare.

\section{Does the Introduction of a Derivative Contract Create Volatility?}

\section{A. Empirical evidence from the futures markets.}

Powers (1970) investigates the effects of the introduction of a futures market on 
the volatility in the underlying cash market for pork bellies and live choice-grade cattle. He examines differences in average weekly cash price variation for the 4-year periods before and after futures contract trading. By differencing the data, he removes positively autocorrelated price variation components and focuses on the volatility of idiosyncratic price increments. He finds that the idiosyncratic component of cash price volatility falls by a statistically significant amount during the period when futures are trading.

The evidence on the relationship between volatility and futures contract trading for GNMA pass-through certificates is dated and somewhat unclear. ${ }^{16}$ Froewiss (1978) investigates the effects of GNMA futures trading on weekly the return volatility of GNMA pass-through certificates. To remove systematic macroeconomic effects, he regresses spot GNMA returns on the returns of 10-year Treasury bonds for samples before and after the introduction of the GNMA futures contract. He finds no significant difference in the slope coefficient estimates across the pre- and post-futures trading samples, but does finds statistically significant evidence that the regression standard error declined after the futures contract introduction.

Figlewski (1981) examines the volatility effects associated with the introduction of GNMA futures trading. In contrast to Froewiss, Figlewski measures GNMA contract price volatility. In apparent contrast to Froewiss's findings, Figlewski concludes that the introduction of GNMA futures trading coincided with an increase the price volatility in the GNMA pass-through market. He speculates that the additional price volatility likely owes to the trading activities of uninformed GNMA futures traders.

Simpson and Ireland (1982) revisit the GNMA futures trading issue. To investigate volatility effects, they regress yields on GNMA pass-through certificates on the 10year Treasury Bond rate, the yields on FNMA securities and dummy interactive variables that allow for parameter shifts during the futures contract period. Simpson and Ireland do not detect any futures trading induced changes in their regression

\footnotetext{
${ }^{16}$ The contract terminated trading in the late 1980s.
} 
slope coefficients. Because they use a dummy variable approach, they assume that the regression error variance is constant and do not test for the idiosyncratic variance reduction found by Froewiss.

Aside from the fact that the aforementioned studies are difficult to reconcile in part because they consider different volatility measures (return, price, and yield), Edwards (1988) takes issue with the methodologies used in these aforementioned studies. All three studies use simple regressions which include the contemporaneous prices or yields on closely related financial instruments to "control" for economy-wide effects on GNMA pass-through certificate volatility. Edwards concludes that the estimates in these studies are subject to endogenous variable bias as the absence of arbitrage requires that the "control" variables used in the regressions are endogenous and heavily influenced by the introduction of the futures contracts.

Edwards (1988) considers the behavior of cash market volatility in samples surrounding the introduction of 4 financial futures contracts: S\&P500, Value Line, 90Day Eurodollars and 90-Day T-Bill Futures contracts. Edwards measures volatility before and after the introduction of each futures contract excluding data during the 1979-1982 period when the Federal Reserve altered its operating procedures. Following the introduction of futures contract trading, except for stocks in 1987, volatility was lower in all cash markets in all years after the introduction of a futures contract. Although he does recognize the expiration-day volatility effects found by Stoll and Whaley (1987), because these effects are small and transitory, Edwards concludes that, on balance, the statistical evidence strongly suggests that cash market volatility has been lower subsequent to the introduction of the financial futures contracts considered in his study.

Harris (1989) investigates the hypothesis that the introduction of S\&P500 index derivative contracts increases the volatility of the underlying instruments. Harris uses a regression model to explain the yearly return variance characteristics for stocks included in the S\&P500 index and the yearly return variances for a sample of compa- 
rable non-index stocks. Harris examines volatility differences for each year between 1975 and 1987. Prior to index futures trading, Harris finds no statistically significant difference in return volatility after controlling for each stock's beta, size, price level and a measure of trade frequency. Subsequent to the introduction of index futures trading, however, Harris finds that the short-horizon returns of S\&P500 stocks are more volatile when compared to comparable non-S\&P500 stocks. The average differences in S\&P500 daily stock return volatility during the futures trading period are very small, between 0.03 and 0.14 percent, and likely insignificant economically when compared to an average daily return standard deviation of about 2 percent in his sample. Although the estimated daily differences are small, the post-futures daily return volatility differences are, however, statistically different from zero in 1985, 1986 and 1987.

Jegadeesh and Subrahmanyam (1993) provide some results that may in part explain the Harris (1989) "excess volatility" findings as a consequence of competitive market making behavior and not speculative excesses. Jegadeesh and Subrahmanyam test a hypothesis advanced by Subrahmanyam (1991) and Gorton and Penacchi (1991). The hypothesis suggests that, because the adverse selection charges implicit in the average bid-asked spreads of individual stocks are likely to be much larger than the adverse selection component of a stock index future market-maker's quote, uninformed traders face incentives to redirect their trades from individual stocks to the index futures contract. The migration of uninformed traders increases the proportion of informed traders faced by the market-makers for individual stocks, and individual share bid-ask spreads are predicted to widen accordingly.

To test the uniformed trader migration hypothesis, Jegadeesh and Subrahmanyam (1993) examine month-end bid-asked spreads for a sample of firms included in the S\&P500 index and a random sample of non-index firms with roughly comparable size in a period that encompasses the introduction of S\&P500 index futures trading. After controlling for the common bid-asked spread explanatory variables, they find 
that average proportional spreads increased subsequent to the introduction of index future trading. Moreover, they find that bid-asked spreads increased significantly more for S\&P500 stocks, but the increase in the magnitudes of implied trading costs is not economically significant. These changes in bid-asked spreads could, at least in part, explain the finding of Harris (1989) as the wider bid-asked spreads could imply a greater bid-asked spread bounce component in daily stock return volatility estimates.

Hong and Subrahmanyam (1994) use intra-day data to assess the impacts that may have been imparted by the introduction of the MMI index futures contract on the bid-asked spreads and volatilities of the individual stocks in the MMI index. Although the MMI was introduced after the S\&P500, and all MMI stocks belong to the S\&P500 index, no intra-day data is available to study the effects of the S\&P500 futures contract introduction. Using intra-day data on selected stocks during 1984 (the MMI began trading on July 23, 1984), the authors find that, consistent with the findings of Jegadeesh and Subrahmanyam (1993), subsequent to the introduction of the MMI futures contract, MMI stocks on average experienced a statistically significant increase in their bid-asked spreads after controlling for other common bid-asked spread determinants (size, volatility, price, volume). Although statistically significant, the magnitude of the average change is unimportant economically. When examining intra-day volatility, Hong and Subrahmanyam remove the effects of bid-asked spread bounce and find no evidence that the introduction of MMI futures trading altered intra-day volatility in the sample period.

Kamara, Miller and Siegel (1992) study the effects of S\&P500 futures market trading on the return distribution of the S\&P500 index. Using univariate non-parametric tests to correct for the non-normality of the underlying return distribution, in contrast to Edwards (1988), they find that daily return distributions exhibit higher volatility in the post-futures sample period. Similar to Harris (1989), they find that longerhorizon return volatility is unaffected by the introduction of futures trading. Despite the measured differences in daily return volatility, the authors conclude that the ob- 
served changes in volatility do not owe to the introduction of the stock index futures contract. Rather, they show that, if the pre-futures and post-futures sample periods are randomly split, the data show statistically significant evidence of changing daily return variances. They conclude that daily return variances are non-stationary, and the non-stationarity is unrelated to the introduction of futures trading.

Kamara, Miller and Siegel also examine the number of outlier returns in the pre- and post-futures trading period. They cannot reject the hypothesis that there are more outliers in the sample period with futures trading - indeed the data show that positive return outliers are far more prevalent when futures are trading. If October 1987 is excluded from the sample however, outliers are equally likely with or without futures. In a multivariate analysis intended to control for macro-economic sources of variation in S\&P500 returns Kamara, Miller and Siegel examine whether the regressions residual volatility differs between the pre- and post-futures trading samples. If October 1987 is excluded from the sample, the post-futures residual volatility is significantly smaller than the residual volatility before S\&P500 futures were introduced. Including October 1987, the post futures residual variance is almost twice as large as the pre-futures sample residual variance. They conclude that, unless one believes that the 1987 Crash was caused by the futures markets, futures markets do not appear to have increased the S\&P500's "excess volatility".

Bessembinder and Seguin (1992) examine the relationship between the cash volatility of the S\&P500 index, trading volume in both the cash and futures market, and open interest in the futures market over the sample period January 1978 to September 1989. They decompose cash and futures markets volumes into three components that correspond with the long-term trend, a transitory expected component, and an unexpected component. Bessembinder and Seguin find that the unanticipated component of cash trading volume is positively related to volatility in the spot market, and the introduction of futures contract trading attenuates this volatility-volume relationship. They also find that volatility in the cash market is negatively related to 
the expected component of futures trading volume. Thus, unlike the well-known positive volume-volatility relationship that is evident in the cash market, increases in the predicable component of futures trading volume are associated with lower, not higher, cash market volatility. As in the cash market, they find that unexpected futures trading volume is positively related to cash market volatility. Bessembinder and Seguin suggest that their results are consistent with the hypothesis that futures markets improve the liquidity and the depth of markets. They find no evidence that supports the hypothesis that futures markets are a conduit for destabilizing speculation.

Although the empirical evidence relating to the introduction of equity index futures contracts suggests that derivative market introductions have, on average, had a stabilizing influence on stock return volatility, there is some evidence that suggests that the existence of derivatives products may have exacerbated transitory spikes in volatility. For example, Stoll and Whaley (1987) found that the introduction of stock-index futures led to significantly higher cash market volatility on index-futures expiration days, and indeed recognition of these effects led to changes in contract expiration procedures that seem to have attenuated expiration day volatility effects. ${ }^{17}$ Another potential example of derivative related transitory volatility is the behavior of S\&P500 stock returns during the October 1987 Crash. Although it is unclear whether the underlying order imbalances owe to the existence of the S\&P500 index futures contract, Blume, MacKinlay and Terker (1989) find evidence that, during the 1987 Crash period, stocks included in the S\&P500 index experienced larger transitory increases in volatility than did non-S\&P500 stocks.

\footnotetext{
${ }^{17}$ See, for example, Stoll and Whaley (1991) or Chen and Williams (1994).
} 


\section{B. Empirical evidence from the options markets.}

Skinner (1989) examines the effect of option listing on the volatility of underlying stock returns. Using a sample of 304 option listings over the period April 1973 to December 1986, Skinner finds that, on average, an option listing event is associated with a 17 percent decline in total daily return volatility. Roughly 70 percent of the firms in Skinner's sample experienced volatility declines. If individual volatility estimates are deflated by the average daily market volatility over each event window, volatility declines by about 10 percent for the median firm in Skinner's sample. He finds that option listing has no statistically significant effect on firms' systematic risks and, on average, stock trading volume increases about 17 percent in the 6month period following option listing. After adjusting for changes in overall market trading volume, the average firm experienced an excess volume increase closer to 4 percent. Trading volume increased the greatest amount for the smallest firms in the sample.

Conrad (1989) examines the stock price and volatility effects associated with the introduction of listed options trading for a sample of 96 stocks which listed options between December 1974 and December 1980. Conrad finds that, on average, individual stocks experience statistically significant positive abnormal returns and reductions in their average total return variance subsequent to the introduction of options trading. Conrad estimates that an equally-weighted portfolio of these stocks would experience an option-listing gain of about 2 percent. Consistent with Skinner, she finds that stocks' market model betas are unaffected by the introduction of options trading, and so reductions in volatility owe to declines in stocks' idiosyncratic variances.

DeTemple and Jorian (1990) examine the effects of options listing and delistings on the returns of the underlying stocks. In a sample of 300 option listings over the period April 1973 through December 1976, they find that an option introduction generates cumulative abnormal returns that average 2.8 percent, and stocks experience on average about a 7 percent reduction in return variance over the two-week window 
surrounding the option listing date. The decline in return volatility does not owe to the recorded price increases, as the magnitude of volatility changes is not statistically related to the magnitude of the price changes recorded in the sample. Consistent with other researchers, DeTemple and Jorian find that most of the variance increase owes to a decrease in firms' idiosyncratic risks as market model betas are little changed by the event. In contrast, the authors find that option delisting (32 events) generate negative cumulative abnormal returns (about 2 percent) and increases (about 9 percent) in return volatility.

DeTemple and Jorian also find evidence of statistically significant market-wide positive abnormal returns associated with option listing events. They estimate that the equally weighted market portfolio experienced a cumulative abnormal return of 1.5 percent (1.1 percent for the value-weighted) in the two weeks surrounding option listing events. Moreover, for individual stock option listings that followed the introduction of index options in 1982, the price and volatility effects associated with option listing are no longer statistically significant. The authors suggest that these market-wide effects are consistent with the large size of the firms on which options are introduced as well as the implications of the theoretical model of Detemple and Jorion (1988). The Detemple-Jorion model predicts that the introduction of an option into an incomplete market will cause both own and cross-security price effects whereas the introduction of an option that does little alter market completeness will have little price impact.

Chamberlain, Cheung and Kwan (1993) investigate the volume, volatility and liquidity effects associated with the introduction of option trading on 37 companies listed on the Toronto Stock Exchange over the period November 1979 through January 1987. The authors examine changes in measures of volatility, volume, and the bidasked spread from a period 4 months before, to 4 months after the introduction of a stock option. Controlling for market-wide volatility, volume, and liquidity effects, they find that, on average, the introduction of option trading was associated with a 
slight decline in volatility, a slight increase in trading activity, and a slight decrease in the bid-asked spread. None of the estimated changes in their sample are, however, statistically significant.

Damodaran and Lim (1991) study the effects of option introduction on the return generating processes for a sample of 200 stocks in a 500 day window before and after option introduction. They document that, on average, the introduction of an option lowers total daily return volatility and the residual volatility of daily market model residuals. Their results suggest that average total daily return volatility declined by about 24 percent and the sample average excess return volatility declined by 22.5 percent. Damodaran and Lim also decompose the return variance into two components: an intrinsic value component, and a noise component. The noise component can be further decomposed into a bid-asked spread effect and an idiosyncratic noise term. Damodaran and Lim find that the reduction in return volatility on average owes to a reduction in the noise term which in part owes to a reduction in the average bid-asked spread. If the sample is partitioned into firms that experienced variances increases and decreases, they find that, on average, while variance declines owe to declines in the both intrinsic and the noise components of return variance, the decline in the noise component is more substantial. When firms experience variance increases subsequent to option introduction, the variance increase appears to owe primarily to an increase in the intrinsic return component of volatility. Moreover, stocks that show increases in variance also show evidence of significantly faster spread of adjustments to intrinsic value information shocks whereas stocks that show declining variance show no significant changes in their speed of adjustment parameters. Thus the data are consistent with the hypothesis that option introduction increase the efficiency of underlying stock prices by speeding up the price adjustment process and, on average, reducing the "noise" component in daily returns. 


\section{Margins and Volatility in the Futures Markets}

\section{A. Theoretical Results.}

There are many theoretical models that relate futures margin requirements to trading activity and price volatility in the futures contract. There are substantial literatures that investigate both the theory of prudential margin requirements, and theories that attempt to relate margin requirement changes to changes in the speculative behavior of agents.

In futures markets, margin requirements set the counterparty collateral rules that help ensure contract performance. ${ }^{18}$ This so-called prudential function is generally associated with margin requirements on clearinghouse guaranteed derivative contracts although, given settlement procedures, a stock purchase is actually a forward contract subject to default risk. For example, if the price of a clearinghouse guaranteed derivative contract moves against a clearinghouse counterparty, or if an option is exercised against them, the clearinghouse counterparty may have an incentive to default on their contract obligation. To minimize a counterparty's incentive to default, the clearinghouse requires that the counterparty post collateral or initial margin with the clearinghouse. A significant literature discusses the optimal approach for setting prudential margin requirements. ${ }^{19}$ A uniform implication of the prudential margin literature is that, other things equal, margin requirements should be set so that they are positively related to expected futures contract price volatility. Thus, if futures clearinghouses follow efficient prudential margin setting procedures, one should observe a positive relationship between futures margin requirements and futures contract price volatility regardless of any effect that margin may have on the activities of speculators.

In the literature that relates margin requirements to the behavior of futures traders, most models follow Telser (1981) and assume that margin requirements im-

\footnotetext{
${ }^{18}$ See Telser (1981) for an extensive discussion.

${ }^{19}$ A partial list of references includes, Telser (1981), Tomek (1985), Figlewski (1984), Edwards (1983), Gay, Hunter, and Kolb (1986), Fishe and Goldberg (1986), Craine (1992), Fenn and Kupiec (1993), Moser (1993), Kupiec (1994), Kupiec and White (1996), and Day and Lewis (1997).
} 
pose a liquidity cost on futures market participants. Telser argues that all agents have a precautionary demand for liquid asset holdings like Treasury Bills. Treasury Bills can also be posted to satisfy futures margin requirements. Despite the fact that the Treasury Bill owner still accrues interest, T-Bills posted as margin deposits no longer satisfy an agent's demand for precautionary balances. Other things equal, a higher margin requirement will induce a contraction in an agent's futures positions so that an agent's overall endowment can support both his futures position margin requirement and the agent's precautionary demand for liquid balances.

Hartzmark (1986) considers the effects of altering margin requirements on the price volatility and level of trading activity in futures markets. He develops a theoretical framework which includes groups of traders that differ in their price expectations, risk aversions, optimal cash holdings, and their perception of the covariance between spot and futures price changes. In his model, a uniform change in the margin requirement imposes differential changes in liquidity costs across agents owing to differences in agents' characteristics and overall expectations profiles. Because of these unobservable differences in liquidity costs, the margin requirement is not a tool that can effectively be used to encourage the selective exit of those agents causing the unwarranted price volatility in the Hartzmark model. Because a margin change will cause an unpredictable shift in the composition of the trading population, it will have unpredictable effects on price volatility.

Pliska and Shalen (1991) formulate a theoretical model that is designed to investigate the effects of margin requirements and position limits on futures trading activity and price volatility. Their model incorporates an exogenous hedger demand and multiple speculators with heterogeneous expectations. Margin requirements are assumed to impose a cost in proportion to the absolute value of a futures position. Speculators transact in the futures market by maximizing a mean-variance utility function based on a noisy expectation of the spot price. Pliska and Shalen show that margin costs induce a bid-asked spread discontinuity into individual speculator's demand 
functions. As margins are increased, each speculators bid-asked spread widens, and in aggregate, speculators' trading demands fall and open interest declines. Although Pliska and Shalen are unable to analytically establish the implications for volatility of a change in margin requirements, they investigate volatility effects in a numerical simulation exercise. They find that, once margin requirements are increased beyond a threshold level, increases in margin requirements increase volatility.

There is another potential channel through which futures margin requirements may affect the underlying instrument's cash price volatility. The ability to default on a clearinghouse guaranteed derivative contract may be valuable to a clearinghouse counterparty. It can be formally demonstrated that the value of this implicit default option is equal to the value of a put option written on the instrument that underlies the contract. This implicit option is granted to the counterparty by the clearinghouse. ${ }^{20}$ The strike price on this implicit put option is, in part, determined by the contract's prudential margin requirement. ${ }^{21}$ Since a clearinghouse does not explicitly charge for this default put option, the clearinghouse should adjust margins so that the option is valueless to all its counterparties. Otherwise, agents may demand contracts and take positions simply to profit from a mispriced clearinghouse guarantee. Thus, if a contract's margin requirement is set inappropriately low from a prudential standpoint, contract demand could be stimulated. Such a situation could result in solvency problems for the clearinghouse with associated effects on market volatility.

\section{Empirical evidence.}

Fishe, Goldberg, Gosnell, and Sinha (1990) study the relationship between initial margin requirements and price volatility using data on 10 futures contracts traded on the CBOT over the 1972-1988 sample period. They find that, consistent with

\footnotetext{
${ }^{20}$ See for example, Fishe and Goldberg (1986), Craine (1992), and Day and Lewis (1997).

${ }^{21}$ The strike price is also implicitly set by the rigor of clearinghouse membership standards and the ease with which clearinghouse default losses can be recovered in the courts in the event of default.
} 
theories of prudential margin management, the CBOT clearinghouse's initial margin requirement is higher, the higher is a contract's price, the higher is average intraday price volatility, and lower the smaller is contract open interest. Examining the effects of all initial margin changes on 10 CBOT contracts from 1972-1988, there is mixed evidence concerning volatility effects across contracts. Some contracts show volatility increases, some decreases, and some show no evidence of change. The authors conclude that their evidence does not support the hypothesis that changes in margins have a systematic effect on futures price volatility.

Fishe and Goldberg (1986) investigate the relationship between margin changes, volume, and open interest on all futures contracts traded on the CBOT between 1972-1978. They find that a 10 percent increase in initial margin requirements re-

duces open interest by between $\frac{1}{3}$ to $\frac{1}{2}$ percent on nearby contracts; for intermediate and longer-term contracts, higher margins reduce open interest, but not by a statistically significant magnitude. They also find that trading volume is weakly positively associated with margin changes. This evidence is consistent with their open-interest finding because intra-day volume is not margined.

Kupiec (1993) studies the relationship between margin requirements on the S\&P500 futures contract and the intra-day volatility of S\&P500 stock index returns. The study measures futures margin requirements as the hedge initial margin requirement divided by the contract value on the nearest term quarterly S\&P500 futures contract. This measure of futures margin requirements is a measure of the leverage available in an S\&P500 index futures contract. S\&P500 intra-day return volatility is estimated using the range estimator suggested by Parkinson (1980) over the sample period July 1987, through July 1989 and thus include the 1987 Crash period. The results of the analysis suggest that, consistent with expected clearinghouse behavior, high margin rates in the futures market tend to be associated with periods of high intra-day S\&P500 stock index return volatility. Kupiec finds no evidence that supports the hypothesis that low margin rates in the futures market are associated with above average volatility 
in the cash market.

Moser (1992) analyzes the relationship between futures return volatility and changes in margin requirements for the S\&P500 stock index futures contract and for the Deutschemark futures contract. Moser finds strong evidence that margins and volatility are related. Consistent with the prudential management of margins, he finds that changes in return volatility lead changes in futures margin requirements and no evidence that changes in margin requirements cause changes in volatility.

Hardouvelis and Kim (1995) examine metals futures contracts. They exclude silver contracts during the Hunt Brothers squeeze period arguing that the special circumstances of the period would contaminate their sample. Hardouvelis and Kim find strong evidence that high metals futures margins reduce contract open interest, but no evidence that higher margins attenuate contract price volatility. Indeed their evidence suggests that any empirical margin-volatility relationship in the data owes to the prudential activities of the futures clearinghouses. Higher volatility leads the clearinghouse to increase margins, but the increase in margin has no measurable effect on contract price volatility subsequently. Hardouvelis and Kim (1996), examine the same data and model volatility including a jump process. This added technical embellishment does not uncover any new compelling evidence. They conclude that their empirical evidence suggests that futures clearinghouses react to higher volatility by raising futures margin requirements.

Day and Lewis (1997b) consider the relationship between margin requirements and expected volatility in the crude oil futures market. They use the prices of options on oil futures contracts and a stochastic volatility options pricing model to extract estimates of the term structure of implied volatility in the crude oil futures market. They examine the reaction of their forward volatility estimates to changes in the margin requirements on crude oil futures contracts. They find that, consistent with the prudential risk management function of margins, the clearinghouse appears to raise (lower) margins following an increase (decrease) in implied volatility. Although 
clearinghouses may alter margins upon observing changes in volatility conditions, Day and Lewis's statistical evidence does not support the hypothesis that clearinghouse margin changes affect the magnitudes of their forward volatility estimates. Their results clearly suggest that return volatility changes in the crude oil market cause futures margin changes, but futures margin changes do not cause any systematic change in return volatility.

As discussed earlier, it is theoretically possible that futures clearinghouses may create the potential for excess volatility by under-margining clearinghouse-guaranteed derivative contracts, Although possible, little evidence suggests that this is likely to be a widespread problem. Craine (1992) attempts to estimate the value of the implicit put option created by an under-margined clearinghouse guarantee. Using data on S\&P500 futures contract margins over alternative sample periods, Craine finds that these implicit options are valueless in most instances. The week of the October 1987 market Crash is, however, an exception. Craine estimates that during this week, the default put option associated with an S\&P500 futures clearinghouse guarantee had positive value. According to his estimates, the put was only valuable for a brief period as, by week-end, the clearinghouse posted a significant increase in margin requirements that eradicated any default put option value.

In a more recent study, Day and Lewis (1997) also model the clearinghouse guarantee as a default put option owned by the clearinghouse counterparty. In contrast to Craine, Day and Lewis model the guarantee as a barrier option, and estimate its value for NYMEX oil contracts over the period November 1986 to March 1991, a period which includes the oil price volatility associated with Iraq's invasion of Kuwait. Similar to Craine's findings, Day and Lewis find that, on average, the clearinghouse sets maintenance margins sufficiently high so that the implicit default option on crude oil futures contracts is valueless. Day and Lewis do, however, detect transitory periods of heightened oil price volatility in which margins were set sufficiently low so that the implicit guarantee default option could have had positive value. In both the Craine 
and Day and Lewis studies, the default option value is calculated ignoring the performance incentive-enhancing effects created by clearinghouse exchange standards, membership capital requirements, and financial condition monitoring. Although the default option value calculations are informative, whether or not the calculations imply that the exchanges were truly under-margining contracts is an open question.

\section{Conclusion}

After examining the academic evidence that investigates the relationship between margin and volatility in both the cash and futures markets, and considering the results of studies that measure the effects of derivative market introductions, this study concludes that there is no substantial body of scientific evidence that supports the hypothesis that margin requirements can be systematically altered to manage the volatility in stock markets. The empirical evidence shows that, while high Reg T margin requirements may reduce the volume of securities credit lending, and high futures margins do appear to reduce the open interest in futures contracts, neither of these measurable effects appears to be systematically associated with lower stock return volatility. The evidence to date suggests that, contrary to the leverage arguments advanced by the pyramiding-depyramiding hypothesis and explicitly accepted by many of the official studies of the 1987 stock market crash, there is no scientific evidence to support the hypothesis that tightening leverage constraints in either the cash or equity derivative markets will reduce stock return volatility. 


\section{References}

[1] Bessembinder, Hendrik, and Paul Seguin (1992). "Futures Trading Activity and Stock Price Volatility,", The Journal of Finance, Vol. 47, No. 5, pp. 2015-2034.

[2] Blume, M., A. MacKinlay, and B. Terker (1989). "Order Imbalances and Stock Price Movements on October 19 and 20, 1987," Journal of Finance, Vol. 44, No. 4, pp. $827-848$.

[3] Chatrath, Arjun, Sanjay Ramchander, and Frank Song (1995). "Does Options Trading Lead to Greater Cash Market Volatility," The Journal of Futures Markets, Vol. 15, No. 7, pp. 785-803.

[4] Chamberlain, Trevor, C. Sherman Cheung, and Clarence Kwan (1993). "Option Listing, Market Liquidity and Stock Behavior: Some Canadian Evidence," Journal of Business, Finance and Accounting, Vol. 20, No. 5, pp. 687-698.

[5] Chance, Don (1990). "The effects of margins on volatility and derivative markets: A review of the evidence," Monograph Series in Finance and Economics, No. 1990-2, New York University Solomon Center.

[6] Chen, Chao, and James Williams (1994). "Triple-Witching Hour, The Change in Expiration Timing, and Stock Market Reaction," The Journal of Futures Markets, Vol. 14, No. 3, pp. 275-292.

[7] Choi, Hong and Avanidhar Subrahmanyam (1994). "Using Intraday Data to Test for Effects of Index Futures on the Underlying Stock Markets," the Journal of Futures Markets, Vol. 14, No. 3, pp. 293-322.

[8] Conrad, Jennifer. (1989). "The Price Effect of Option Introduction," Journal of Finance, Vol. 44, No. 2, pp. 487-498.

[9] Cox, Charles (1976). "Futures Trading and Market Information," Journal of Political Economy, Vol. 84, No. 6, pp. 1215-1237.

[10] Cox, John and Mark Rubinstein (1985). Options Markets, Prentice Hall, New Jersey.

[11] Craine, Roger (1992). “Are Futures Margins Adequate?" University of California Berkeley Working Paper No. 92-192, April.

[12] Damodaran, Aswath and Joseph Lim (1991). "The effects of option listing on the underlying stock's return processes," Journal of Banking and Finance, Vol. 15 , No. 3 , pp. 647-664. 
[13] Darrat, Ali, and Shafiqur Rahman (1995). "Has Futures Trading Caused Stock Price Volatility?" The Journal of Futures Markets, Vol. 15, No. 5, pp. 537-557.

[14] Day, Theodore, and Craig Lewis, (1997a). "Initial Margin Policy and Stochastic Volatility in the Crude Oil Futures Market," The Review of Financial Studies, Vol. 10, No. 2, pp. 303-332.

[15] Day, Theodore, and Craig Lewis, (1997b). "Margin Adequacy in Futures Markets," memo, Owen Graduate School of Management, Vanderbilt University.

[16] Detemple, Jerome, and Philippe Jorion (1990). "Option Listing and Stock Returns," First Boston Working Paper, No. 89-13, Columbia University.

[17] Detemple, Jerome, and Philippe Jorion (1990). "Option Listing and Stock Returns," Journal of Banking and Finance, Vol 14, No. 4, pp. 781-801.

[18] Detemple, Jerome, and Larry Seldon (1991). "A General Equilibrium Analysis of Option and Stock Marker Interactions," International Economic Review, Vol 32, No. 2, pp. 279-303.

[19] Edwards, Franklin (1983). "The Clearing Association in Futures Markets: Guarantor and Regulator," The Journal of Futures Markets, Vol. 3, No. 4, pp. 369-392.

[20] Edwards, Franklin (1988). "Futures Trading and Cash Market Volatility: Stock Index and Interest Rate Futures," The Journal of Futures Markets, Vol. 8, No. 4, pp. 421-439.

[21] Federal Reserve Board (1984). "A Review and Evaluation of Federal Margin Regulations." Staff study, Board of Governors of the Federal Reserve System, Washington, D.C. December.

[22] Ferris, Stephen and Don Chance (1988). "Margin requirements and Stock Market Volatility," Economic Letters, Vol. 28, No. 3, pp. 251-254.

[23] Figlewski, Stephen (1981). "Futures Trading and Volatility in the GNMA Market," Journal of Finance, Vol. 36, No. 2, pp. 445-456.

[24] Figlewski, Stephen (1984). "Margins and Market Integrity: Setting Margins for Stock Index Futures and Options," Association in Futures Markets: Guarantor and Regulator," The Journal of Futures Markets, Vol. 4, No. 3, pp. 385-416.

[25] Fishe, Raymond, and Lawrence Goldberg (1986). "The Effects of Margins on Trading in Futures Markets," The Journal of Futures Markets, Vol. 6, No. 2, pp. 261-271. 
[26] Fishe, R. L. Goldberg, T. Gosnell, and S. Sinha (1990). "Margin Requirements in Futures Markets: Their Relationship to Price Volatility," The Journal of Futures Markets, Vol. 10, No. 5, pp. 541-554.

[27] France, Virginia (1991). "The Regulation of Margin Requirements," in Margins \& Market Integrity, Lester Telser, editor. Mid America Institute, Chicago, Probus Publishing Company.

[28] Froewiss, Kenneth (1978). "GNMA Futures: Stabilizing or Destabilizing? Federal Reserve Bank of San Francisco, Economic Review, Spring, pp. 20-29.

[29] Goldberg, Michael (1985). "The Relevance of Margin Regulation," Journal of Money, Credit, and Banking, Vol. 17, No. 1, pp. 521-527.

[30] Grube, R.C., O. M. Joy, and J.S. Howe (1987). "Some Empirical Evidence on Stock Returns and Security Credit Regulation in the OTC Equity Market," Journal of Banking and Finance, Vol 11, No. 1, pp. 17-31.

[31] Grube, R.C., O. M. Joy, and D. Panton (1979). "Market Responses to Federal Reserve Changes in the Initial Margin Requirement," Journal of Finance, Vol. 34, No. 3, pp. 659-674.

[32] Gay, G., W. Hunter, and R. Kolb (1986). "A Comparative Analysis of Futures Contract Margins," The Journal of Futures Markets, Vol. 6, No. 2, pp. 307-324.

[33] Hardouvelis, Gikas. (1988). "Margin Requirements and Stock Market Volatility," FRBNY Quarterly Review, Summer.

[34] Hardouvelis, Gikas. (1989). "Commentary: Stock Market Margin Requirements and Volatility," Journal of Financial Services Research, Vol. 3, No. 2/3, pp. 139151.

[35] Hardouvelis, Gikas. (1990). "Margin Requirements, Volatility, and the Transitory Component of Stock Prices" American Economic Review, Vol. 80, No. 4, pp. 736763.

[36] Hardouvelis, Gikas, and Dongcheol Kim, (1995). "Margin Requirements, Price Fluctuations, and Market Participation in Metal Futures," Journal of Money, Credit, and Banking, Vol. 27, No. 3, pp. 659-671.

[37] Hardouvelis, Gikas, and Dongcheol Kim, (1996). "Price Volatility and Futures Markets," The Journal of Futures Markets, Vol. 16, No. 1, pp. 81-111.

[38] Gordon, G, and G. Pennacchi (1993). "Security Baskets and Index-Linked Securities," Journal of Business, Vol. 66, No. 1, pp. 1-28. 
[39] Harris, Lawrence. (1989). "S\&P500 Cash Stock Price Volatilities," Journal of Finance, Vol. 44, No. 5, pp. 1155-1176.

[40] Hart, Oliver (1975). "On the Optimality of Equilibrium when the Market Structure is Incomplete," Journal of Economic Theory, Vol. 11, No. 3, pp. 418-443.

[41] Hartzmark, Michael (1986). "The Effects of Changing Margin Levels on Futures Market Activity, the Composition of Traders in the Market, and Price Performance," Journal of Business, Vol. 59, No. 2, pp. S147-S180.

[42] Hayes, S. and M. Tennenbaum. (1979). "The Impact of Listed Options on the Underlying Shares," Financial Management, pp. 72-76.

[43] Hong, Choi, and Avavidhar Subrahmanyam (1994). "Using Intraday Data to Test for Effects of Index Futures on the Underlying Stock Markets," The Journal of Futures Markets, Vol. 14, No. 3, pp. 293-322.

[44] Hsieh, D. and M. Miller, (1991). "Margin Regulation and Stock Market Volatility," Journal of Finance, Vol. 45, No. 1, pp. 3-30.

[45] Jegadeesh, Narasimhan and Avanidhar Subrahmanyam (1993). "Liquidity Effects on the Introduction of the S\&P500 Index Futures Contract on Underlying Stocks," Journal of Business, Vol. 66, No. 2, pp. 171-187.

[46] Kahl, Kandice, Roger Rutz, and Jeanne Sinquefield (1985). "The Economics of Performance Margins in Futures Markets," The Journal of Futures Markets, Vol. 5, No. 1, pp. 103-112.

[47] Kalavathi, L. and Latha Shanker, (1991). "Margin Requirements and the Demand for For Futures Contracts," The Journal of Futures Markets, Vol. 11, No. 2, pp. 213-237.

[48] Kamara, Avraham, Thomas Miller Jr., and Andrew Siegel (1992). "The Effect of Futures Trading on the Stability of Standard and Poor 500 Returns," The Journal of Futures Markets, Vol. 12, No. 6, pp. 645-658.

[49] Kupiec, Paul (1989). "Initial Margin Requirements and Stock Returns Volatility: Another Look," Journal of Financial Services Research, Vol. 3, No. 2/3, pp. 189202.

[50] Kupiec, Paul (1993). "Futures Margins and Stock Price Volatility: Is There Any Link?" The Journal of Futures Markets, Vol. 13, No. 6, pp. 677-691.

[51] Kupiec, Paul, and Steve Sharpe. (1991). "Animal Spirits, Margin Requirements and Stock Price Volatility," Journal of Finance, Vol. 46, No. 2, pp. 717-732. 
[52] Kupiec, Paul (1994). "The Performance of S\&P500 Futures Product Margins under the SPAN Margining System," The Journal of Futures Markets, Vol. 14, No. 7, pp. 789-812.

[53] Kupiec, Paul, and A. Pat White (1996). "Regulatory Competition and the Efficiency of Alternative Derivative Product Margining Systems," The Journal of Futures Markets, Vol. 16, No. 8, pp. 943-968.

[54] Largay, James (1973) "100 Percent Margins: Combating Speculation in Individual Security Issues," The Journal of Finance, Vol. 28, No. 4, pp. 973-986.

[55] Largay, James and Richard West (1973) "Margin Changes and Stock Price Behavior," Journal of Political Economy, Vol. 81, No. 2, pp. 328-339.

[56] Manaster, Steven, and Richard Rendleman, Jr. (1982). "Options Prices as Predictors of Equilibrium Stock Prices," Journal of Finance, Vol. 37, No. 4, pp. 1043-1057.

[57] Moore, Thomas (1966) "Stock Market Margin Requirements," Journal of Political Economy, Vol. 74, No. 2, pp. 158-167.

[58] Moser, J. (1992). "Determining margin for futures contracts: the role of private interests and the relevance of excess volatility," Federal Reserve Bank of Chicago Economic Perspectives, Federal Reserve Bank of Chicago, March/April, pp. 2-18.

[59] Parkinson, Michael (1980). "The Extreme Value Method for Estimating the Variance of the Rate of Return," Journal of Business, Vol. 53, No. 1, pp. 61-65.

[60] Pliska, Stanley, and Catherine Shalen (1991). "The Effects of Regulations on Trading Activity and Return Volatility in Futures Markets," The Journal of Futures Markets, Vol. 11, No. 2, pp. 135-151.

[61] Powers, Mark (1970). "Does Futures Trading Reduce Price Fluctuations in the Cash Markets," The American Economic Review, Vol. 60, No. 5, pp. 460-464.

[62] Salinger, M. (1989). "Stock Market Margin Requirements and Volatility: Implications for Regulation of Stock Index Futures," Journal of Financial Services Research, Vol. 3, No. 2/3, pp. 121-138.

[63] Seguin, Paul (1990). "Stock Volatility and Margin Trading," Journal of Monetary Economics, Vol 26, No. 1, pp. 101-121.

[64] Seguin, Paul, and Gregg Jarrell (1993). "The Irrelevance of Margin: Evidence from the Crash of '87," The Journal of Finance, Vol 48, No. 4, pp. 1457-1473. 
[65] Simpson, Gary and Timothy Ireland (1982). "The Effect of Futures Trading on the Price Volatility of GNMA Securities," The Journal of Futures Markets, Vol. 2, No. 4, pp. 357-366.

[66] Skinner, Douglas J (1989). "Options Markets and Stock Return Volatility," Journal of Financial Economics, Vol. 23, No. 1, pp. 61-78.

[67] Schwert, G.W. (1989a). "Why Does Stock Market Volatility Change Over Time?" Journal of Finance, Vol. 44, No. 5. pp. 1115- 1154.

[68] Schwert, G.W. (1989b). "Margin Requirements and Stock Volatility," Journal of Financial Services Research, Vol. 3, No. 2/3, pp. 153-164.

[69] Stein, Jeremy (1987). "Information Externalities and Welfare-Reducing Speculation," Journal of Political Economy, Vol. 95, No. 6, pp. 1123-1145.

[70] Stoll, H. and R. Whaley (1987). "Expiration Day Effects of Index Options and Futures," Financial Analysts Journal, Vol. 43, pp. 16-28.

[71] Stoll, H. and R. Whaley (1991). "Expiration Day Effects: What has Changed?" Financial Analysts Journal, Vol. 58, pp. 58-72.

[72] Subrahmanyam, Avavidhar (1991). "A Theory of Trading in Stock Index Futures," Review of Financial Studies, Vol. 4, No. 1, pp. 17-51.

[73] Tomek, William (1985). "Margin on Futures Contracts: Their Economic Roles and Regulation." In Futures Markets: Regulatory Issues," Anne Peck editor. American Enterprise Institute.

[74] Turnovsky, Stephen and Robert Campbell, (1985). "The Stabilizing and Welfare Properties of Futures Markets: A Simulation Approach," International Economic Review, Vol. 26, No. 2, pp. 277-303.

[75] Weller, Paul and Makoto Yano (1987). "Forward Exchange, Futures Trading and Spot Price Variability: A General Equilibrium Approach," Econometrica, Vol. 55, No. 6, pp. 1433-1450. 